\title{
Dealing with English Majors' Written Errors in Chinese Universities
}

\author{
Ping Wang \\ School of Foreign Studies, Jiaxing University, China 314001 \\ Email: pwang886@hotmail.com
}

\begin{abstract}
Error correction, a common phenomenon observed in teaching activities, is closely studied in the present paper, with particular attention paid to teachers' usual practice and students' attitude. The study shows that while teachers and students share such common views as the importance of error correction and the types of errors that need correcting, there exist considerable discrepancies as to the techniques of error correction. For instance, students do not favour the overall correction, though practiced by most teachers. Such a controversy requires teachers to make possible improvements about their current error correction practice. A systematic strategy is then suggested in the paper, and relevant arrangement of the writing class is discussed, showing the theoretical and practical significance of the paper.
\end{abstract}

Index Terms - error correction, teachers' practice, students' preference, discrepancy.

\section{INTRODUCTION}

It is important for both teachers and students to accept the fact that errors are an inevitable part of the learning process (Davies \& Pearse, 2002:78). It is through students' errors that "we can see what they are struggling to master, what concepts they have misunderstood and what extra work they might need" (Lavery, 2001). Therefore, errors are often a sign of learning in language acquisition process. However, teachers' behaviours in dealing with students' written errors vary, reflecting different attitudes they hold towards written errors. Some teachers tend to correct all the errors while some tend to be tolerant and still some others do not correct at all.

According to the relevant literature on error-correction (Brown, 1998; Tedick, 1998; Lee, 2005), the following techniques are generally practised by teachers of English to correct students' writing: Overall correction: The teacher corrects all mistakes and provides the correct versions; Error correction codes: The teacher underlines mistakes and uses a code to indicate the nature of the error. For instance, the teacher may use the symbol "Sp." to refer to "wrong spelling", WW for "wrong word", and the like; Peer correction: It is a technique where learners correct each other's work, rather than the teacher doing this; Self-correction: The students themselves, rather than the teacher or their peers, correct their own work.

Still there are other possible approaches for the teachers to give feedback to students' written work. To illustrate, the teacher may ask the students to refer to the textbooks or other reference books to find out correct versions of their errors. Whatever form the correction technique takes, it is acknowledged that each approach has its strengths and weaknesses.

Then key questions are, accordingly, which of the techniques English teachers frequently use, how students like them, and whether they are effective or not. This paper, based on a study, aims to investigate the correction of written errors in the context of Chinese universities.

The key questions raised by this research are borne out of gaps in existing studies and of the researchers' experiences as teachers of English. The questions addressed in the paper are as follows:

$\checkmark \quad$ What techniques are often applied by teachers to correct students' written errors?

$\checkmark \quad$ What do the students think of such correction techniques?

$\checkmark \quad$ What are the common points and discrepancies between teachers' practice and students' preference, if any?

$\checkmark \quad$ How can teachers improve the effectiveness of error correction? In addition, if necessary, how should teachers adjust the arrangement of the writing class?

This paper then, is an attempt to answer these questions in the following five sections. The first section reviews the background literature on written error correction. The second section outlines the research method, followed by the results obtained from the statistical analysis and evidence. The third and fourth sections provide a discussion of research findings, as well as highlighting their implications for teaching practice. The fifth section is a conclusion of the whole research and its limitations.

\section{LITERATURE REVIEW}

As for the written error correction techniques, overall correction is generally acknowledged as one of the easiest ways to correct errors because the correct forms are provided, but students may not understand why they made those errors and tended to make the same errors when they wrote other sentences. Such cases have shown, to some extent, 
that teachers' excessive attention to students' errors results in frustration for students and exhaustion for teachers. It is very disconcerting for students to see many words crossed out, new words added, and an array of marginal comments all usually written in blood red letters. Thus "when they are faced with an outbreak of unsightly red scribble all over their neatly presented work, is it tempting for them to ignore the corrections and file under 'bin', or even lose heart altogether?" (Lake, 2002:16)

Hairston (1986:117) warns that writing teachers should not be "composition slaves". In accordance with Hairston, Hillocks (1986) and Knoblauch \& Brannon (1981: 1-4) have cast doubt on the effectiveness of error correction. Unfortunately, Hairston' and others' advice do not seem to have been taken. The plain fact is that many teachers are still slaving over students' writing.

Ferris (1995:48) states, "Indeed, a hands-off approach to error correction may not work because students attend to and appreciate their teachers pointing out their grammar problems". Despite the controversy about issue of error correction, two factors remain clear. First, "writing teachers seem to believe that responding to student errors is a vital part of their job" (Ferris, 1995: 49). Second, "students are eager to receive teachers' feedback on their writing and believe that they benefit from it" (Leki, 1991: 204; Swales, 1998:151).

Until now, research on error correction has predominantly focused on teachers, for example, the techniques they use in providing error feedback (Ferris \& Robert, 2001: 161). Much less has been done to find out what students' reflection is about error feedback. Cohen (1987: 57-69, 1991:13), Cohen \& Cavalcanti (1990:16), Ferris (1995: 42, 1997:315-319), Hedgcock \&Lefkowitz (1994:141-146) and Radechi \& Swales (1998:355-365) have conducted studies to investigate student preferences about and reactions to teachers' feedback. Their research findings suggest that students wish teachers to correct errors for them. Both ESL and EL students expressed moderate preference for the use of correction symbols, and both disliked the teacher using the red pen. Brown (2000:253) puts a compromise view that student preferences should neither be ignored nor put on a pedestal. Any mismatches between teacher practices and student preferences must be examined because students' preferences are not necessarily more effective for being preferred.

How teachers might respond to students' written work to encourage improvements in their writing has been a matter of debate. It seems clear that once teachers have formed the right attitudes towards errors and examined student preferences regarding the feedback they have received, students will be helped and motivated in their writing and this will ultimately lead to higher English proficiency in writing.

Based on the Chinese university context, this paper compares teacher practices on written errors and student preferences rather than only criticise the overall correction, since understanding teachers' and students' views on written error correction can help teachers "predict expectation conflicts that may contribute to student frustration, anxiety, lack of motivation, and in some cases, ending of foreign language study" (Kern 1995:71). In other words, handed properly, teacher error feedback could address individual needs and motivate students.

\section{THE STUDY}

\section{A. Research Method}

A questionnaire and an interview were used to gather data mainly from teachers and students in Chinese universities. The research was designed mainly to discover whether there are discrepancies between teacher practices and student preferences in written error correction. Given the particular relevance, the educational context of Chinese universities assumes in the study, the deputy presidents are also included in the present study, as they are in charge of teaching affairs, and their requirements can be rather influential to teachers' teaching practice. However, the feedback from presidents will only be used for reference in that it may provide certain valuable explanations for our findings.

\section{Research subjects}

In order to obtain a complete picture of research objectives, the researchers conducted two phases of study, with the $1^{\text {st }}$ phase in Xinjiang Uygur Autonomous Region and the $2^{\text {nd }}$ phase Zhejiang Province and Jiangsu Province. The subjects of the research are 540 students of English majors, 59 teachers and 10 deputy presidents from different universities in the 3 provinces in China. Subjects are randomly selected from a larger sample. See the table below for more detailed information.

TABLE 1

RESEARCH SUBJECTS

\begin{tabular}{|c|c|c|c|c|c|c|c|}
\hline \multirow{2}{*}{ Items } & \multicolumn{2}{|c|}{ Students } & \multicolumn{3}{c|}{ Teachers } & \multicolumn{2}{c|}{ Deputy Presidents } \\
\cline { 2 - 9 } & Male & Female & Young & Middle-aged & Senior & Key University & $\begin{array}{c}\text { Non-key } \\
\text { university }\end{array}$ \\
\hline $\mathbf{1}^{\text {st }}$ phase & 44 & 46 & 3 & 3 & 3 & 1 & 0 \\
\hline $2^{\text {nd }}$ phase & 260 & 190 & 15 & 20 & 15 & 3 & 6 \\
\hline Total & \multicolumn{3}{|c|}{540} & 59 & & 10 \\
\hline
\end{tabular}

\section{Research procedures}

The research in each phase proceeded in the following four stages:

In the first stage, the students were tested on writing a composition entitled Campus Life of not less than 200 words. In the second stage, the students' written work was photocopied, and was given to be corrected by teachers with 
different techniques. One copy was corrected with the overall correction technique. The students received another copy with no correction at all. The students received a third copy with the selective correction and finally a fourth copy was corrected with each kind of error underlined and coded with symbols. In the third stage, the students, teachers and deputy presidents were asked to complete questionnaires giving information about their attitudes to, and preferences for error correction. In addition, their opinions were collected about the kinds of techniques with regard to error correction and their writing class in general. When the students finished the questionnaires, half of the students were organized in groups of five using the no-correction copies, trying 'the peer-correction'. Another half was trying 'self-correction', that is, they had to edit their own work. In the fourth stage, the interviews were conducted with 60 students, 18 teachers and 9 deputy president in charge of teaching affairs. The results are reported below, with the percentage of responses beside each question.

\section{Instruments}

Two instruments (the questionnaire and interview) are adopted in the study with different research objectives.

A: Question items in the Questionnaire:

* How to correct?

* What to correct?

* Amount of correction?

* Amount of effectiveness?

* Attitudes towards errors?

* What do you think of your writing class? (For students only)

Since there were three kinds of subjects involved in the study, we made three versions of questionnaire for them respectively:

a. Questionnaire for teachers

b. Questionnaire for students

c. Questionnaire for presidents

$\mathrm{B}$ : Interview questions:

* What do you think of the correction technique that you are currently using? (For teachers)

* What do you think of your writing class? \& Do you like how your teacher corrects your compositions? (For students)

* Do you think it effective to use the overall correction technique in students' English compositions? If not, could you please offer some suggestions? (For deputy presidents)

\section{Data Collection}

The two phases of research were conducted in regular English class hours. To ensure that the participants give reliable answers, the researchers, together with the university English teachers, explained to the students that the data collected would be for research use only. The researchers then observed the whole responding process and collected the questionnaires within roughly 20 minutes. As for the interviews, the researchers asked the questions in the environment familiar to the subjects, like classrooms for students and offices for teachers and presidents. In this way, the subjects were generally relaxed, which helped to guarantee the reliability and validity of the study.

\section{B. Findings of Questionnaires}

\section{Question item 1: How to correct?}

a. Which of the following techniques do you prefer when correcting students' written errors? (For teachers)

b. Which of the following techniques do you want your teachers to use when they correct your written errors? (For students)

c. Which of the following techniques do you expect the teachers to use when they correct students' written errors? (For presidents)

The findings of item 1 in Questionnaire are shown in Table 2 below.

TABLE 2

FINDING OF ITEM 1 IN QUESTIONNAIRE

\begin{tabular}{|c|c|c|c|}
\hline Error correction techniques & Students & Teachers & Presidents \\
\hline Underlining the error & $1 \%$ & $0 \%$ & $0 \%$ \\
\hline The teacher writes the correct answer. & $11 \%$ & $96 \%$ & $100 \%$ \\
\hline Self-correction: students receive no correction at all. & $0 \%$ & $0 \%$ & $0 \%$ \\
\hline $\begin{array}{l}\text { The teacher underlines errors and each type of error } \\
\text { coded with symbols introduced. }\end{array}$ & $47 \%$ & $4 \%$ & $0 \%$ \\
\hline The teacher only corrects certain types of error & $37 \%$ & $0 \%$ & $0 \%$ \\
\hline $\begin{array}{l}\text { Just a cross written next to a line where an error } \\
\text { occurs }\end{array}$ & $0 \%$ & $0 \%$ & $0 \%$ \\
\hline Peer-correction & $4 \%$ & $0 \%$ & $0 \%$ \\
\hline
\end{tabular}

Question item 2: What to correct? 
a. What kind of errors do you often correct in students' writings? (For teachers)

b. What kind of errors do you expect your teachers to correct in your writings? (For students)

c. What kind of errors do you think the teachers should correct in the students' writings? (For presidents)

The findings of item 2 in Questionnaire are shown in Table 3 below.

TABLE 3

FINDINGS OF ITEM 2 IN QUESTIONNAIRE

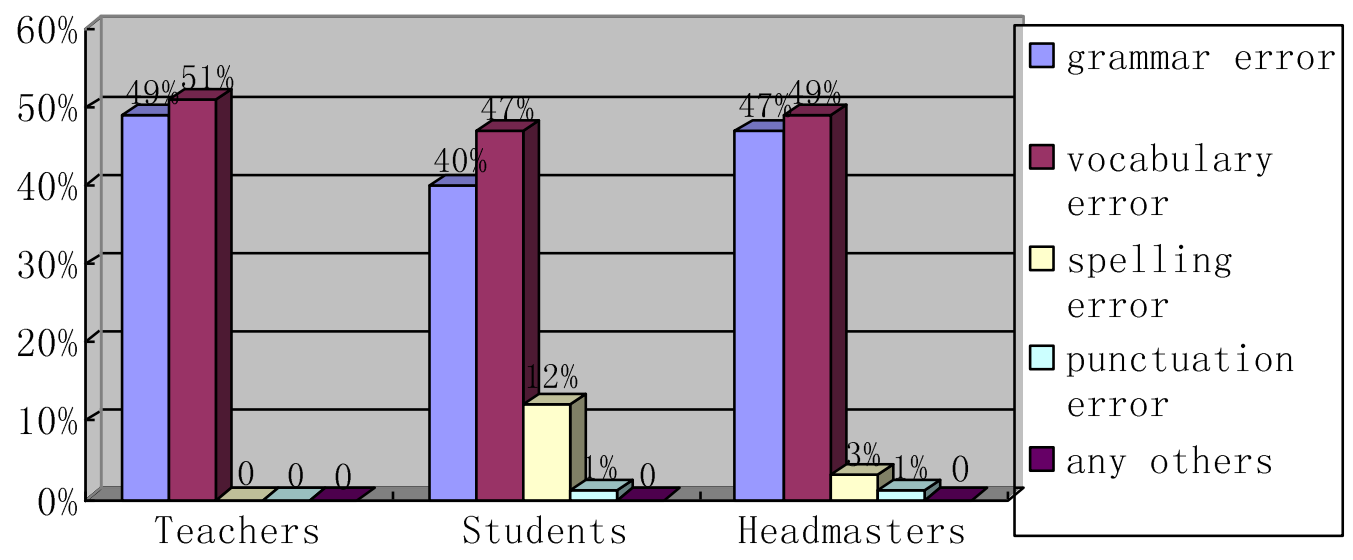

\section{Question item 3: Amount of correction}

(1). Attitudes towards present amount of error correction

a. For the present amount of error correction, do you think you need to correct more, less, or the same? (For teachers)

b. Would you like your teacher to correct you more, less, or the same? (For students)

c. As for the present amount of error correction, do you think the teachers should correct students' writing errors more, less or the same? (For presidents)

The findings of item 3 (1) in Questionnaire are shown in Table 4 below.

Table 4: Findings of Item 3 (1) in Questionnaire

(2). Frequency of error correction

a. How often do you provide feedback on the organization of the students' writing? (For teachers)

b. How often do you want your teacher to provide feedback on the organization of your compositions? (For students)

c. How often do you expect the teachers to provide feedback on the organization of students' writing? (For presidents)

The findings of item 3 (2) in Questionnaire are shown in Table 5 below.

TABLE 5

FINDINGS OF ITEM 3 (2) IN QUESTIONNAIRE

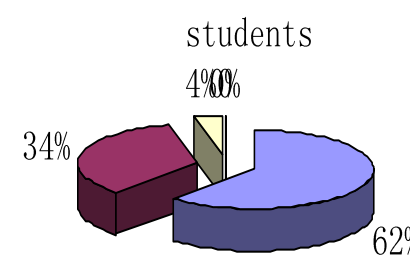

Teachers

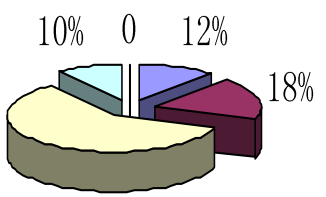

$60 \%$

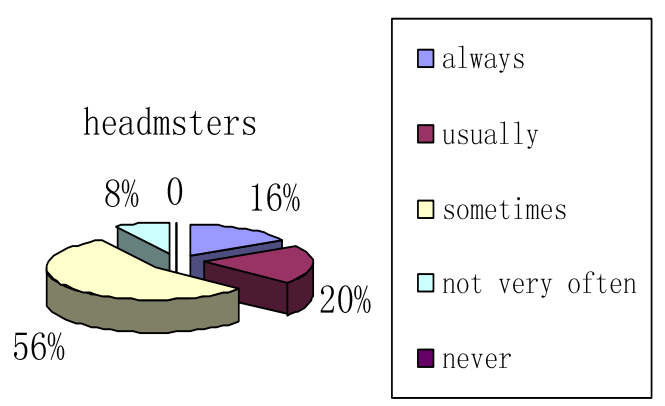

\section{Question item 4: Amount of effectiveness}

a. How effective do you think of your current written-error correction. (For teachers)

b. How effective do you think of your teachers' current written-error correction. (For students)

c. How effective do you think of the teachers' current written error correction. (For presidents)

The findings of item 4 in Questionnaire are shown in Table 6 below. 
TABLE 6

FINDINGS OF ITEM 4 IN QUESTIONNAIRE

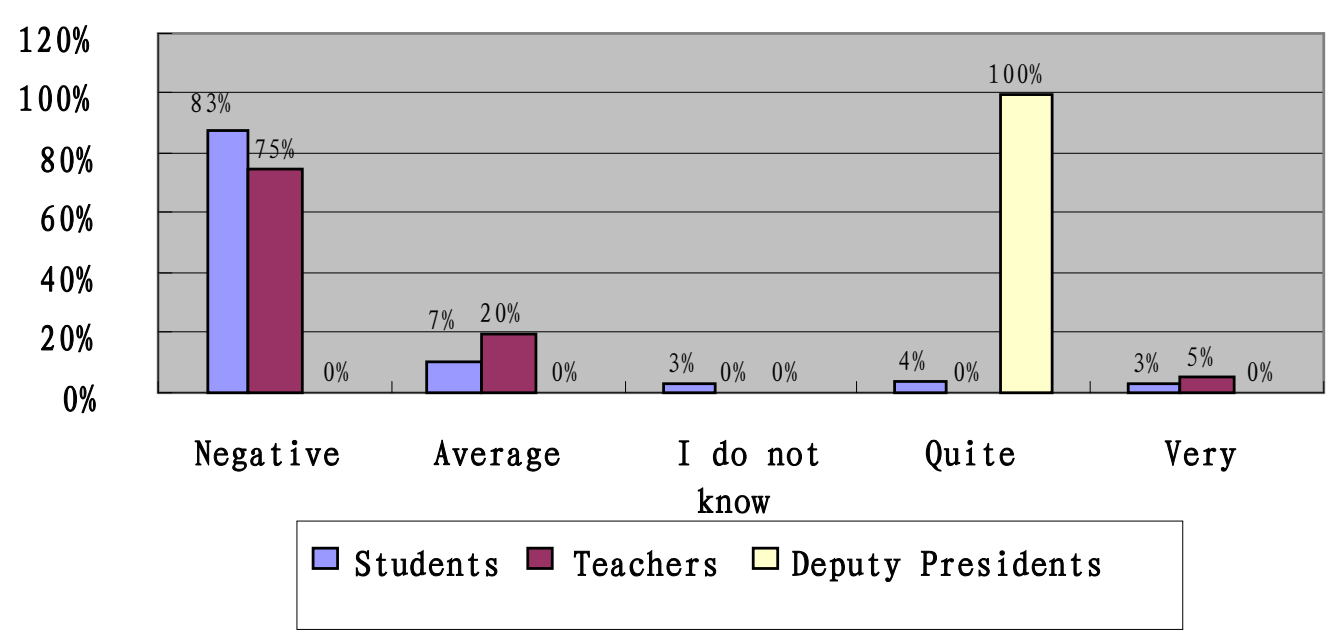

\section{Question item 5: Attitudes towards written errors}

a. How important is it to you that there are as few errors as possible in the students' writing? (For teachers)

b. How important is it to you that you have as few errors as possible in your writing? (For students)

c. How important is it to you that there appear as few errors as possible in the students' writing? (For presidents) The findings of item 5 in Questionnaire are shown in Table 7 below.

TABLE 7

FINDINGS OF ITEM 5 IN QUESTIONNAIRE

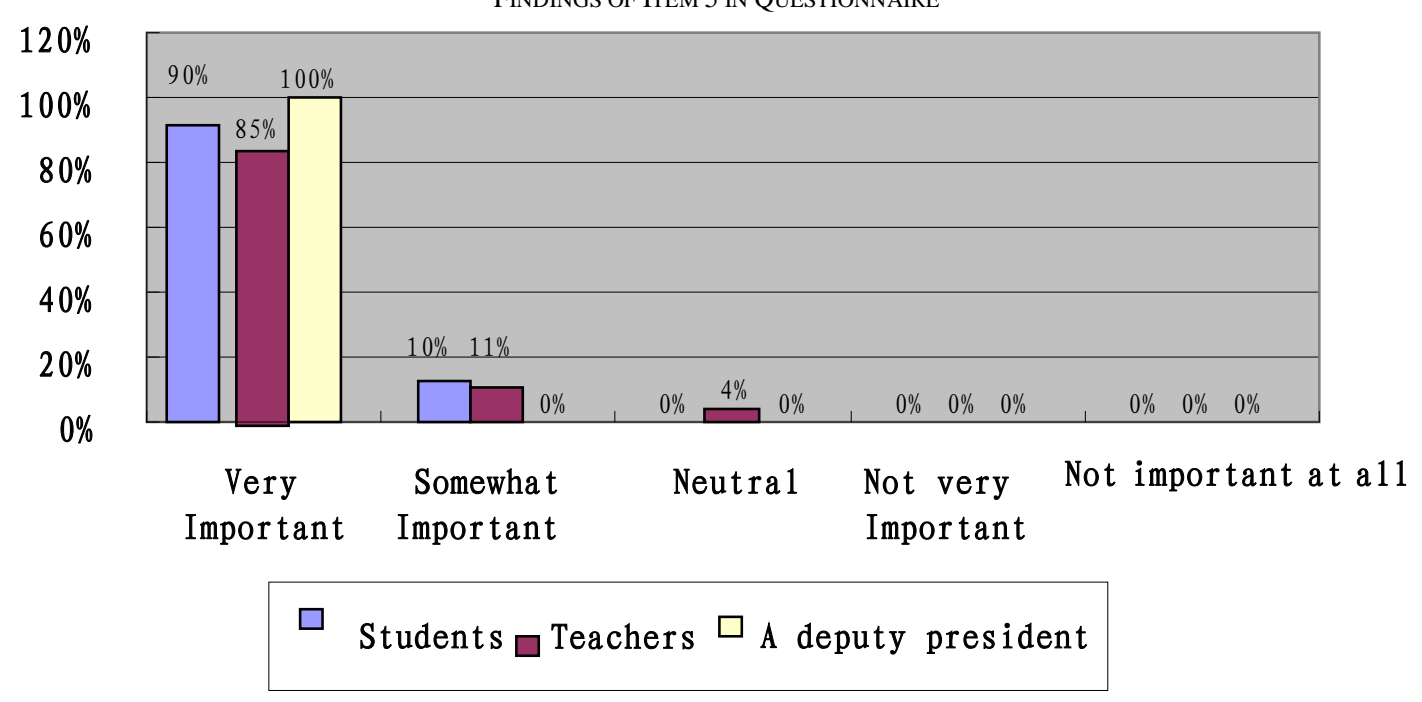

Question item 6: What do you think of your writing class? (For students)

The findings of item 6 in Questionnaire are shown in Table 8 below. 
TABLE 8

FINDINGS OF ITEM 6 IN QUESTIONNAIRE

\begin{tabular}{|c|c|}
\hline Items & Students \\
\hline 1. Your teacher always helps you to plan your writing in your writing class. & $1 \%$ \\
\hline 2. Your teacher always helps you during your writing process. & $2 \%$ \\
\hline 3. Your teacher just declares the topic and then sits down in the front. & $99.8 \%$ \\
\hline 4. I am afraid of being monitored by teachers when I am writing. & $99 \%$ \\
\hline 5. I like to be guided to write in writing class. & $100 \%$ \\
\hline 6. I never feel sure when I am asked to write a composition in class. & $89 \%$ \\
\hline 7. I like to write my ideas down in the English composition class. & $2 \%$ \\
\hline 8. In class, I may get nervous because of the fear of making errors. & $99.9 \%$ \\
\hline 9. I never seem to be able to write down my ideas in English clearly. & $98 \%$ \\
\hline 10. I have a terrible time organizing my ideas in an English composition. & $90.2 \%$ \\
\hline 11. I do not like my English composition to be evaluated by teachers of English. & $99.4 \%$ \\
\hline 12. I like my English writing to be evaluated by foreign teachers. & $100 \%$ \\
\hline 13. I often use computers and emails at home. & $99.2 \%$ \\
\hline
\end{tabular}

\section{Interview Evidence}

\section{Feedback from the teachers}

The three groups of teachers, as classified in terms of age in Table 1, provided rather different feedback, showing their different attitudes towards error correction. For young teachers, they liked to correct differently after they saw the students' feedback. They hoped that the school would allow them to correct beyond the traditional ways, i.e. the overall correction. A typical example is Miss Yang, 26, with 2-year English teaching experience, who responded, "Overall correction is my general practice to deal with students' written errors. But since the students showed their dislike to this method, I may try other correction techniques in future work."

Most of the professors thought differently that the data collected was full of fallacy. They did not think that such an argument about error correction should be put to the vote. They would not acknowledge that the overall correction would demotivate students in learning to write. They refused to make any change.

"Discussing and justifying one's own correcting style is a challenging and rewarding experience, which can serve as a reference point for a future discussion", said a middle-aged teacher surnamed Zhang. After seeing the students' feedback, they chose to rethink it and they were eager to have dialogues with students.

\section{Feedback from the students}

Though the two phases of study were carried out in two different periods of time and in different parts of China, surprisingly, the students' feedback produced remarkably similar result.

a. Talking about their writing and their writing classes

The students never felt sure when they were asked to write compositions, because they were afraid of making errors. They had great fear of their writing compositions being evaluated by their teachers of English with punishments, while they enjoyed submitting their writing to foreign teachers for evaluation. They reported that they had never had a well-planned guided writing lesson, for their teachers would just give them a topic at the beginning of a lesson, and then he/she would sit in the front or wander in the classroom, disciplining the students. When the bell rang, announcing the end of the lesson, the group leaders of the students would collect their compositions and hand them to the teacher. During the interview, the researchers also noticed that the students had regular access to computers with web browsing and email capabilities, which suggested that it was feasible to use computers and Internet in their writing class.

b. Talking about correction techniques

Most students found it very dispiriting if their written work was covered in red ink, underlined and with words crossed out. The students' reactions to the techniques (errors underlined and each type of error coded with symbols) were very positive. They stated that it was very useful and that it was very easy to find their errors and to correct them because they were helped. Half of the students interviewed thought that general symbols were not particularly helpful.

The students said that some errors were too difficult to correct without any help. The majority said they had difficulties in spotting errors. They were emphatic during interviews that they needed help, but they did hate the overall correction plus teachers' punishment.

They liked the peer-correction or the pair-correction, but they were wondering if they would copy each other's errors. If the teacher only put a cross next to their errors, they might feel that the teacher did not spend sufficient time looking at their work.

During the interview with students, the general impression gained was that the students were crying out for understanding from their teachers, which meant that something must be done to prevent the overall correction. However, for academically weaker students, most of them emphatically stated their preference was for detailed and guided feedback and the questionnaires showed the same result.

\section{Feedback from the deputy presidents}

As the head in charge of school teaching issues, the deputy presidents expected all their staff and students to be admirably industrious and often in need of dissuasion from working too hard. After they looked through the statistics, they all promised that they would consider performing experiments of the approaches preferred by the students in one 
or two classes or that they would discuss in a meeting. For written error correction, one of them suggested that teachers of English should take notes on common errors that students made, and during the correction session in class, teachers should focus on some of the common errors and do some re-teaching.

\section{ANALYSIS AND DISCUSSION}

It is hoped that the investigations on the error correction techniques could represent a form of dialogue between the students and the presidents, between the students and the teachers and between teachers and the school. As the research shows, with regard to the topic of error correction, the teachers and students do share certain common ground, but there also exist discrepancies to their views. Accordingly, the following discussion will proceed from these two aspects.

\section{A. Common Views}

The first shared view is found among almost all research subjects as to the importance of written error correction. As item 5 in Questionnaire suggests, $89 \%$ of the students and $91 \%$ of the teachers and $100 \%$ of the deputy presidents surveyed thought that there should be as few errors as possible in compositions. Although it is certain that the framing of the questions influenced the results of the research, it was amazing for the researchers to observe total support for written error correction among the subjects. This may work as a prerequisite for studying the discrepancies, so as to improve the effectiveness of error correction.

The second common view can be observed in item 2 in Questionnaire, which is about the types of written errors that should be corrected most. All the students and $87 \%$ teachers thought that errors in grammar and vocabulary need most attention. Perhaps students tend to make errors easily in these two aspects, and it is reasonable that poor performance in grammar and vocabulary deserve more efforts in error correction.

Still another common view is outlined in item 4 in Questionnaire, which surveys the effectiveness of current written error correction. The findings show that $83 \%$ of the students and $75 \%$ of the teachers held negative attitudes towards the effectiveness of the overall correction. But why does the practice of the overall correction continue? The answer lies in the voice of the deputy president, that is, he who has the concluding voice in the school and consequently supports the overall correction technique $100 \%$. This reflects another aspect of Chinese culture: the top-down or power-coercive approach. Moreover, overall correction is perhaps the traditional and habitual technique used by Chinese teachers, and it is not easy to alter such practice or replace it with others.

\section{B. Major Discrepancies and Analysis}

In contrast to the common ground shared by teachers and students, there also exist considerable discrepancies in their attitudes. Items 1, 3 and 6 in Questionnaires as well as the interview feedback all show such discrepancies in several different aspects. As shown in Questionnaire 1, for example, the overall correction is still shown as the teachers' and deputy presidents' favoured technique, while the students like to be active, to participate or to be involved in the feedback process.

This is matched with what Leki (1991:203) said, "Students wanted their teachers to show where the error was and to give a clue how to correct it". As James (1998:62) put it, "Note, they did not want the teacher to do the overall correction, but preferred to solve the correction problems at the aid of their teachers' indication or help: they were not looking for the easy way out, but expected to have to work in order to improve." This may well explain why they preferred the correction with symbols, which can provide information on correction, so students can figure out the correct forms by themselves. Students in the survey refuse pure underlining, because students may make wrong guesses about their errors.

Since students' beliefs about the written error correction are "of crucial importance to the success or failure of [their] efforts to master a foreign language" (Rifkin 2000:394), and their juxtaposition with teacher's beliefs highlight areas of conflict, pedagogical implications assume paramount importance. Bada and Okan (2000) argue that many teachers acknowledge the need to understand students' preferences, but may not actually consult learners in planning language classroom activities. This may be for a number of reasons.

Teachers may be restricted by their university policy, institutional practices, as well as personal perceptions about the appropriateness of such initiatives. On another level, teachers may simply be acting on their own beliefs and unwilling to compromise on what they believe to be true. Although Nunan (1988:177) claims that "no curriculum can claim to be truly learner-centred unless the learner's subjective needs and perceptions relating to the processes of learning are taken into account", a certain degree of controversy surrounds the issue on whether it is the teachers who should shift their beliefs in line with their students' views on the written error correction, or vice-versa. Yet, Block (1994) suggests that it is the teachers who should attempt to align their task orientation to that of students, because they have a greater awareness of what goes on in the classroom.

So far, little research on minimizing the discrepancies has been conducted that involves investigations into the effects of instructional interventions, based on Chinese university students' beliefs about the written error correction. No doubt, more research is needed in this area in order to determine the extent of belief change because of teacher intervention. Hofer (2001:372) argues that "there has been a presumption of all those working in this area that educational experiences play a role in fostering development or belief change. However, what types of experiences are most 
conducive? What instructional strategies can be best employed? Although the literature is replete with advice, less research exists that clarifies the relation between methods and types of instruction and personal epistemology".

In the meantime, a number of measures or strategies could be taken to ensure that teacher-learner mismatches are minimized, though at the same time teachers need to be aware that Chinese university students have had a significant emotional investment in previous beliefs. Nonetheless, finding 'middle-ground' may not be an impossible task. However, for teachers, examining and re-examining their own assumptions and beliefs through 'internal dialogues' and reflection on their own practice is of particular importance. . In the Woods' (2003) study, teachers were able to reach a compromise, ensuring that both students' preferences and curricular requirements were met. They were able to do so, having re-examined their previous long-standing beliefs.

\section{IMPLiCATIONS FOR TEACHING PRACTICE}

The efficacy of error correction is a central issue for the theory and practice of writing instruction. Particularly important is evidence regarding a serious problem found in items $3 \& 6$ in Questionnaires and interviews with students: no writing activities were organized in writing classes, which furthered our interests and led us into 20 periods of classroom observations of the writing class (the first 6 in Xinjiang, and the rest 14 periods in Zhejiang and Jiangsu). What we saw is no different from what was read in the questionnaires and heard from interviews with the students. Also in the questionnaire, we can see that the students held a negative and pessimistic attitude towards the writing. They were forced to write and they were afraid of their work being evaluated by the teachers of English, while they did not fear that their work was assessed and evaluated by foreign teachers. So the suggested way of dealing with students' written errors is to plan the writing classes well by designing coherent and guided classroom activities, to teach writing using task-based approaches and to train students to organise their paragraphs or sentences in a coherent way. When teachers are preparing for the writing class, they should ask themselves: “A) Why should we teach writing? B) How should the writing class be planned and organized? C) What is the teacher's role in the teaching of writing? D) What kind of writing should students do?" (Harmer 2000:168)

\section{A. Minimising the Gap: a Process Approach to Writing with Systematic Correction Strategies}

The product-oriented method of teaching writing pays a great attention to the accuracy of the final product but ignores the writing process, discouraging the students from learning to write. From the items $3 \& 6$ in Questionnaires, we can see what really matters is the help that the teacher provides to guide students through the process that they undergo when they are writing. This is called the process approach to writing (Wang 2006:86). In keeping with Wang (2006), Rivers (1986:1-7) argues that many writing weaknesses can be traced back to a lack of thorough, systematic training during the earlier stages of foreign language learning. She also notes that to be effective, systematic training in writing requires systematic correction of individual script.

In view of the present situation of written error correction, as revealed by the research, teachers need to detect the existing problems and solve them accordingly. Identifying and then minimizing the gap is crucial to providing teachers with defendable pedagogical practices that are in line with students' belief and expectations. Accordingly, the implications of the present study can be practically applied in two aspects: adoption of appropriate correction techniques, and systematic organization of the writing class.

\section{B. Some Suggestions}

Based on the research findings and analysis, we hereby propose several suggestions on the organization of the writing class and varied error correction techniques so as to provide some implications for English teaching activities in similar educational settings.

\section{Suggestion 1: Raising students' awareness by using preventative / error-awareness activities}

Based on the analysis of errors, some of the written errors, especially the errors caused by mother tongue interference, can be prevented from occurring. The purpose of using preventative /error-awareness activities is by and large "to encourage them to review and monitor their own written work more carefully; to encourage them to take responsibility for the standard of their own written work; and to help them develop self-help strategies for sorting out grammatical problems" (Brooks \& Grundy 1998:146).

The reason why it is better to be aware of errors in written work and take preventative action is that it is very disheartening to students and teachers alike for a piece of work to be returned covered in red ink.

On Internet, a vast majority of websites consist of multiple-choice and fill-in-the-blank activities. For preventative purposes, the activities from the websites can be used before students start their writing. For remedial purposes, they can be used after students' work has been marked. The repetition of the same structure does not have to be mechanical and boring, and it can be a useful avoiding or remedial technique. It is useful because some errors seem to be the result of strong habit formation, and to break a bad habit, we need to reinforce or replace it with a good one.

\section{Suggestion 2: Systematic correction strategies}

In teaching practice, no matter how much we try to prevent errors with various strategies, no matter how much creative freedom we might like to give the student, or how much we dread the act of correction, ultimately we find ourselves with pen in hand, diligently scanning students' compositions in search of errors and analyzing errors. So, 
finding effective techniques of correcting students' written errors is still a practical task for all EFL teachers, but for Chinese teachers of English it is particularly challenging. Five major ways of proofreading (marked A, B, C, D and E) are discussed as follows.

A. Using games

The games not only help to develop students editing skills in a fun way, but also enable the teacher to focus on key errors without individual students losing face. "Students can catch more than $60 \%$ of their own errors if they are taught to proofread and held to appropriate standards of correctness" (Porte 1988:167-172).

B. The four-step strategy

Doff (1988:68) suggests the four-step strategy for systematic proof-reading. Doff suggests that students read the compositions four times but each time with a different focus.

a. Discussing common errors as a class

From Kroll (2001:219-232), teachers select some of the most common and significant errors students make. And write on the board the sentences that the students themselves have produced in written work containing these errors, which include one or two perfectly correct sentences, also produced by the students. Teachers keep all the sentences anonymous, asking the students to work in pairs, to identify the sentences with errors and decide what exactly is wrong, and correct them. Then teachers check with the whole class and discuss the errors and the rule. Another strategy is to establish "the error of the week" on Monday. It should be a significant error that most learners sometimes make that particular error; the other students should raise their hands. Note who raises their hands first and congratulate them. Of course, the student who makes the error can raise his or her own hand-we often notice our errors the moment we have made them.

\section{$b$. The selective correction}

Teachers may concentrate on one particular area to do error correction work. $36 \%$ of the students investigated in the research like this technique because of the following three possible reasons: one reason may be that students in the selective error correction might feel more confident about composing. A second reason is that the correction might fix corrections in students' long-term memory. A final reason is that the selective correction might improve students' attitudes towards writing and reduce students' writing anxiety more than the other techniques.

c. Using a corrective code

This is a very useful and time saving technique for the busy teacher. It may not be new for the teachers in the Western countries (the foreign teachers working in the university where I did the research frequently use this technique to correct students' written errors), but for the university teachers of English in China, it is perfectly innovative to the overall correction.

Teachers can use a code that indicates to students the types of error they have made and it will involve them in more conscious assessment of what they have produced. For instance, T. (tense), Sp. (spelling), W.W. (wrong word), P. (punctuation), W.O. (wrong order), S-V. (subject verb agreement), ` (omit) etc. For better students, teachers go further than this and simply give references to grammar books, software, or websites where the particular point that the student has improperly produced is dealt with.

The advantage of this technique is that it will lead students, if they are given adequate time, to work out for themselves what is wrong, and to go some way towards correcting it. Many students (48\%) in the present research have shown interests in the use of a code of indications written in margins or over the error.

d. The peer correction

From Harmer (2000:140), teachers ask students to exchange drafts of their work in progress and supply one post-it sticker of each colour the teacher has available to each student. If the teacher only has one colour, he may give each student four post-it notes to start with. It is necessary to explain to the students that are going to make comments on each other's drafts on the post-its and stick them at the most appropriate places on the draft. If students are working with several colours, each colour should be used for a different category of comment. Possible categories include content, spelling, punctuation, accuracy, layout, vocabulary and structure. The teacher can specify which categories the students should use, the teacher can write a list of possible categories on the board and allow them to choose, or the teacher can insist that everyone comments on content and then chooses whichever other categories they think appropriate. Teachers must stress that the purpose is to provide the original writers with useful advice that they can use in a rewrite.

Many students in the research held negative views of the peer correction, because they had the same worry as Hughes J. (2005) did, "there is a danger that a student may be getting incorrect information from a peer, but careful monitoring on your part can resolve this." But we still claim that we should encourage our students to correct each other in pairs or in group work. It encourages team spirit and has the benefit of reinforcing the language in the other students' own minds as well.

C. The self-correction with error logs or checklists

Another strategy that we recommend is to ask the students to keep logs of their errors so that both teachers and students have a record of the errors that keep appearing. Teachers should look over the lists of errors in students' logs and talk to the students about their perceptions of what they were trying to do when they made the errors. If teachers 
discover that they have students with problems that neither they nor their students can solve by keeping logs and discussing the patterns with each other, then consult other teachers or even language specialists for help.

D. The one-to-one correction

From James (1998:247), conferencing allows both students and teachers a chance to trace the causes of the problems arising from students' writing and feedback, and to develop strategies for improvement. During these sessions, teachers can ask direct questions to students in order to gain a deeper understanding of students' writings. In addition, students are able to express their ideas more clearly in writing and to get clarification on any comments that teachers have made. Finally, teachers can use conferencing to assist students with any specific problems related to their writing.

E. Writing encouraging comments

Another thing that teachers must be sure of in teaching writing in Chinese university is that, while views on approaches to error correction may vary, the need to balance error-spotting with words and phrases like "Well done!", "Great!", "That's really good!", "You did very well!". Complementing students on successes and positive reinforcement of what they do well should be integrated in any approach to error correction. It may even have greater benefits than the tireless pursuit of what went wrong.

\section{Suggestion 3: A suggested systematic training approach to teaching writing}

Writing is a skill that has been neglected in English language teaching in universities in China. However, as more and more communication is necessary in all walks, more and more work is done through writing. As teachers of English, we should come to realize the importance of developing students' writing skills. We put forward three suggestions here (marked A, B and C below) to help university teachers of English better organize the writing class and furthermore, improve students' writing abilities.

A. Planning a lesson with integrative skills

The planning of a writing class with integrative skills is an important part of developing students' writing ability. Writing lessons can be planned as integrated skills sessions, moving, for example, from reading/listening, to discussion, to role-play and finally to writing. Of course, this kind of session is possible only if you have sufficient time, as well as in a collaborative group (Harmer 2000:141). Willis (1981:.206) says that before students start to write, teachers should make sure that students 1) can say it; 2) can read it; 3) can understand it; 4) know what teachers want them to do; 5) know how teachers want them to do it; 6) know how and why they are doing it. Such is true of the teaching writing in Chinese universities, because firstly we have found that teaching writing in Chinese universities is in a dilemma; secondly, if the four skills are involved in a writing class, not only will the writing class become active, but also students' writing ability may be improved. Accordingly, some of the students' errors can be avoided. A lesson plan briefly shows the process of teaching a writing class with the four skills integrated.

B. Teaching guided writing

Writing work done in the classroom falls on a continuum from copying to free writing (Brookes \& Grundy 1998:146). Guided writing emphasizes to students that writing is a process with several stages: planning, drafting, revising and proofreading. In practice, firstly students are encouraged to think about the topic before they write. They 'brainstorm' ideas and approaches and discuss the topic with other students, getting new ideas and clarifying their own thoughts (Harmer 2000:140). Teachers can find some similar issues in books, magazines or Internet, and students can see the sample writings. Then the class works on a piece of similar writing together. Students do some preliminary writing exercises, namely, taking notes, answering questions, ordering ideas, linking sentences, etc. Then students can work through some language exercises containing the language that may be useful in their writing on the computers. Finally, they prepare a rough draft of writing for discussion, proofreading and revision.

Students often benefit most when the writing work of the semester can be conceived as one project, phased in stages or logical sequences. Moving through a logical sequence of assignments is one way to increase the level of conceptual difficulty gradually, and to ensure that students build on material they have studied in earlier portions of the syllabus (Harmer 2000:221).

In short, we believe the guided writing is a preferable alternative to simply giving students' titles and leaving them to get on with compositions in the classroom. It is a much more effective way of teaching a writing class.

C. Training students to learn to organise the composition

English (2005:10) stresses, "An important part of writing is awareness of how a text is organised and the impact of that organisation on the reader." Here, English is expressing a great need for organising compositions into coherent pieces of work. For example, she stresses the need for linking of ideas, i.e., within sentences, between sentences and between paragraphs. It is a key aspect of writing development and is typically her and other researchers such as Brookes and Grundy (1998:147) advocate a Western style of writing that. Not only will the teaching procedure in the lesson plan help the teachers, but also it will inevitably help students to understand the underlying processes of writing English compositions. It will moreover enhance students overall grasp of the English language.

\section{CONCLUSION}

Errors are evidence of the learning process and therefore should be viewed with proper attitude. This study investigated teachers' practice of and students' preferences about error correction techniques in the settings of universities in China. 
The research findings suggest that there are both common ground and discrepancies in the views of the two major groups of subjects: university students and teachers of English. Their shared views are revealed in the importance of error correction, the types of errors that need correcting, and the ineffectiveness of current error correction practice.

The discrepancies of their opinions, we believe, demand more of our attention. First, overall correction, though favoured and practiced by most teachers and presidents, does not seem to be popular with students, who expect to participate or be involved in the feedback process. Second, most students would like the teachers to correct their writings less, while teachers and presidents prefer to keep the current amount. Third, the students complained about their ill-structured English writing class and lack of guidance in the writing process.

Based on such findings, we further proposed some suggestions to minimize the gap between teachers' and students' viewpoints as to written error correction. First, the teachers may try to raise students' awareness by using preventative activities. Moreover, the teachers to enhance students' participation and involvement can adopt a systematic error correction strategy, like games, selective correction, using corrective codes, writing encouraging comments, etc. Finally, a systematic approach to teaching writing was put forward to help teachers better organize and guide students' composition writings. On the whole, it is believed that the discrepancies between teacher practices and student preferences will be narrowed when English majors in Chinese universities are given a more active role in teachers' dealing with written work errors and the writing classes.

However, the study has some limitations. On the one hand, the findings of the study are limited by the small sample size and the short period of time during which the study was conducted. Therefore, the findings may appear particular and its external validity may be affected. We also concede that the data collected was probably influenced by some internal (psychological) and external (environmental) factors. For example, a student or a teacher may be in a particularly good mood or be distracted by things that concern him/her outside the classroom. Thus, a replication of this research on a larger scale would be appropriate in order to gain results that can be generalised beyond the sample of the study.

\section{REFERENCES}

[1] Bada, E., \& Okan, Z. (2000). Students' language learning preferences. TESL-EJ, 4 (3), A-1. Retrieved 17th January, 2007 from http://writing.Berkley.edu/TESLEJ/ ej15/a1.html

[2] Barkhuizen, G.P. (1998). Discovering learners' perceptions of ESL classroom teaching/learning activities in a South African context. TESOL Quarterly, 32 (1).

[3] Block, D. (1994). A day in the life of a class: Teacher/learner perceptions of task purpose in conflict. System, 22(4), 473-486.

[4] Brookes, A. \& Grundy, P. (1998). Beginning to write. Cambridge: Cambridge University Press.

[5] Brown, C. (1998). Errors in language learning and use: Exploring error analysis. Longman.

[6] Brown, H.D. (2000). Principles of language learning and teaching. Longman.

[7] Cohen, A D, \& Cavalcanti M C. (1990) Feedback on compositions: Teacher and student verbal reports. In B Kroll (Ed.), Second Language Writing: Research Insights for the Classroom. Cambridge: Cambridge University Press.

[8] Cohen, A.D. (1991). Feedback on writing: the use of verbal report. Studies in second language acquisition. Cambridge: Cambridge University Press.

[9] Davies, P. \& Pearse, E. (2002). Success in English teaching. Shanghai: Shanghai Foreign Language Education Press.

[10] Doff, A. (1988). Teach English. Cambridge: Cambridge University Press.

[11] English, F. (2005). A handbook for university study. Cambridge: Cambridge University Press.

[12] Ferris, D.R. (1995). Student reactions to teacher response in multi-draft composition classroom. TESL Quarterly 8

[13] Ferris, D.R. (1997). The influence of teacher commentary on students' revision. TESOL Quarterly 31.

[14] Ferris, D. \& Roberts, B. (2001). Error feedback in L2 writing classes: How explicit does it need to be? Journal of second language writing, 10 (3), 161-184.

[15] Hairston, M. (1986). On not being a composition slave. In C.W. Bridges(Ed.), Training the new teacher of college composition Urbana, IL: NCTE.

[16] Harmer, J. (2000). How to teach English. Beijing: Foreign Language Teaching and Research Press.

[17] Hedgcock, J. \& Lefkowitz, N. (1994). Feedback on feedback: assessing learner receptivity to teacher response in L2 composing. Journal of Second Language Writing , 3 (2), 141-163.

[18] Hillocks, G. (1986). Research on written composition: New directions for teaching. Urbana, IL: ERIC Clearninghouse on Reading and Communication Skills and the National Conference on Research in English.

[19] Hofer, B.K. (2001). Personal epistemology research: Implications for learning and teaching. Journal of Educational Psychology Review, 13 (4), 353-383.

[20] Hughes, J. (2005). Find the right way to right the wrongs Guardian Weekly from www.guardianweekly.co.uk

[21] James, C. (1998). Errors in language learning and use-- Exploring error analysis. Longman.

[22] Kern, R. G. (1995). Students' and teachers' beliefs about language learning. Foreign Language Annals, 28 (1), 71-92.

[23] Knoblauch, C. \& Branon, L. (1981). Teacher Commentary on Student Writing: The State of the Art. Freshman English News, $10(2), 1-4$.

[24] Kroll, B. (2001). Considerations for teaching an ESL/EFL writing course. In M. Celce-Murcia (Ed.), Teaching English as a second or foreign language (3rd ed.) (pp.219-232). Boston, MA: Heinle and Heinle.

[25] Lake, J. (2002). Correcting written work. IATEFL Issues April-May 2002.

[26] Larsen-Freeman, Diane \& Michael H. Long.(1991). An introduction to second language acquisition research. New York: Longman.

[27] Lavery, C. (2001). Language assistant from http://www.teachingenglish.org.uk/ 
[28] Lee, I. (2005). Error correction in the L2 writing classroom: What do students think? TESL Canada Journal, 22 (2).

[29] Leki, I. (1991). The preference of ESL students for error correction in college-level writing classes. Foreign language annals, $24(3)$.

[30] Nunan, D. (1988). The learner-centred curriculum. Cambridge: Cambridge University.

[31] Press.Porte, G. (1988). Poor language learners and their strategies for dealing with new vocabulary. English language teaching journal, 42 (3).

[32] Radecki, P. M. \& Swales, J. M. (1988). 'ESL student reaction to written comments on their written work', System,16 (3).

[33] Rifkin, B. (2000). Revising beliefs about foreign language learning. Foreign Language Annals, 33(4), 394

[34] Rivers, W.M. (1986). Comprehension and production in inactive language teaching. The modern language journal, 70.

[35] Swales, J. (1988). 20 years of the TESOL Quarterly. TESOL Quarterly, 22(1).

[36] Tedick, D. (1998). Research on error correction and implications for classroom teaching Longman. from http://www.carla.umn.edu/immersion/acie/vol1/May1998.pdf\#search=\%22error\%20correction\%20and\%20error\%20analysis\% $\underline{22}$

[37] Wang Q. (2006). A Course in English language teaching. Beijing: Higher Education Press.

[38] Willis, J. (1981). Teaching English through English. Longman.

[39] Woods, D. (2003). The social construction of beliefs in the language classroom. In P. Kalaja, \& A. M. F. Barcelos (Eds.), Beliefs about SLA: New Research Approaches (pp. 201-229). Dordrecht: Kluwe Academic Publishers

Ping Wang is Associate Professor at College of Foreign Studies, Jiaxing University. His research interests are in applied language studies and the cultural awareness in language teaching. His work has appeared in a number of scholarly journals and edited Wiley-Blackwell, Routledge, or among others.

Professor Wang is a member of IATEFL and a member of World Chinese Association. 